\title{
The earliest occupation of Europe: a short chronology
}

\author{
WIL ROEBROEKS \& THIJS VAN KOLFSCHOTEN*
}

\begin{abstract}
A reappraisal of the artefactual and chronological evidence for the earliest occupation of Europe - with proper attention to its limitations and its reliability - makes for a short chronology. The first solid traces of hominid activities in this part of the world are around 500,000 years old.
\end{abstract}

\section{Introduction}

When did the first humans leave Africa, and at what time did they move into Europe, the Americas or Australia? There are many answers to such questions, but hardly any agreement. Establishing the earliest documented evidence for human occupation has always involved controversy, usually centred around the artefactual character of assemblages and/or their chronological position. The situation is not different for the earliest traces of occupation of Europe. Despite the large number of meetings devoted to this topic the dates given to the first 'Europeans' vary enormously, depending on the book or journal one opens. On the 'very old' side, Bonifay \& Vandermeersch (1991) present a number of sites allegedly dating from earlier parts of the Early Pleistocene, around two million years ago ( $c f$. Ackerman 1989; Delson 1989). An age of about one million years is considered a good estimate for the first occupation of Europe by most workers ( $c f$. Rolland 1992), placing the earliest traces in the end of the Lower Pleistocene, as at Le Vallonet in France (De Lumley et al. 1988) and Kärlich A in Germany (Würges 1986; 1990). In contrast to these 'long chronologies' we suggest in this paper that Europe's earliest human traces are in fact considerably younger, dating from well into the Middle Pleistocene.

Our paper begins with a short review of the artefactual character of assemblages and the chronological framework of the Quaternary, focusing on how sites are put in a chronological succession (section 2). In section 3 we survey the biostratigraphical position of important mammalian assemblages (from both archaeological and non-archaeological sites), while section 4 reviews early sites in central and northwestern Europe. We then turn to evidence from other parts of Europe, and close with brief discussion of the implications.

\section{The earliest occupation of Europe: artefacts and chronology \\ 2.1 Evaluating the artefactual character of assemblages}

One century ago, Palaeolithic archaeologists were involved in a fierce debate over the alleged existence of Tertiary humans in Europe. Eolithophiles, both on the continent and in Britain, presented thousands of flints from Tertiary deposits, that in their opinion were humanly worked implements. The long lasting debate over the character of 'eoliths' produced a vast literature on the subject, summarized in popular handbooks from those days, like Sollas' Ancient hunters and their modern representatives (1911), Obermaier's Der Mensch der Vorzeit (1912) and Boule's Les Hommes Fossiles (1921). Very detailed field observations and experiments created a vast body of knowledge concerning the variety of artefact-like forms produced by various natural processes.

The crux of the matter is elegantly summarized by Warren (1920: 250):

What is important ... is the fact that such phenomena as the flaking of flints and occasional bulbs and also edge-knapping are produced by causes entirely apart from direct human effort. The likeness between the flaking produced by Nature and that produced by

* Faculty of Pre- and Protohistory, Leiden University, PO Box 9515, 2300 RA Leiden, The Netherlands.

ANTIQUTTY 68 (1994): 489-503 


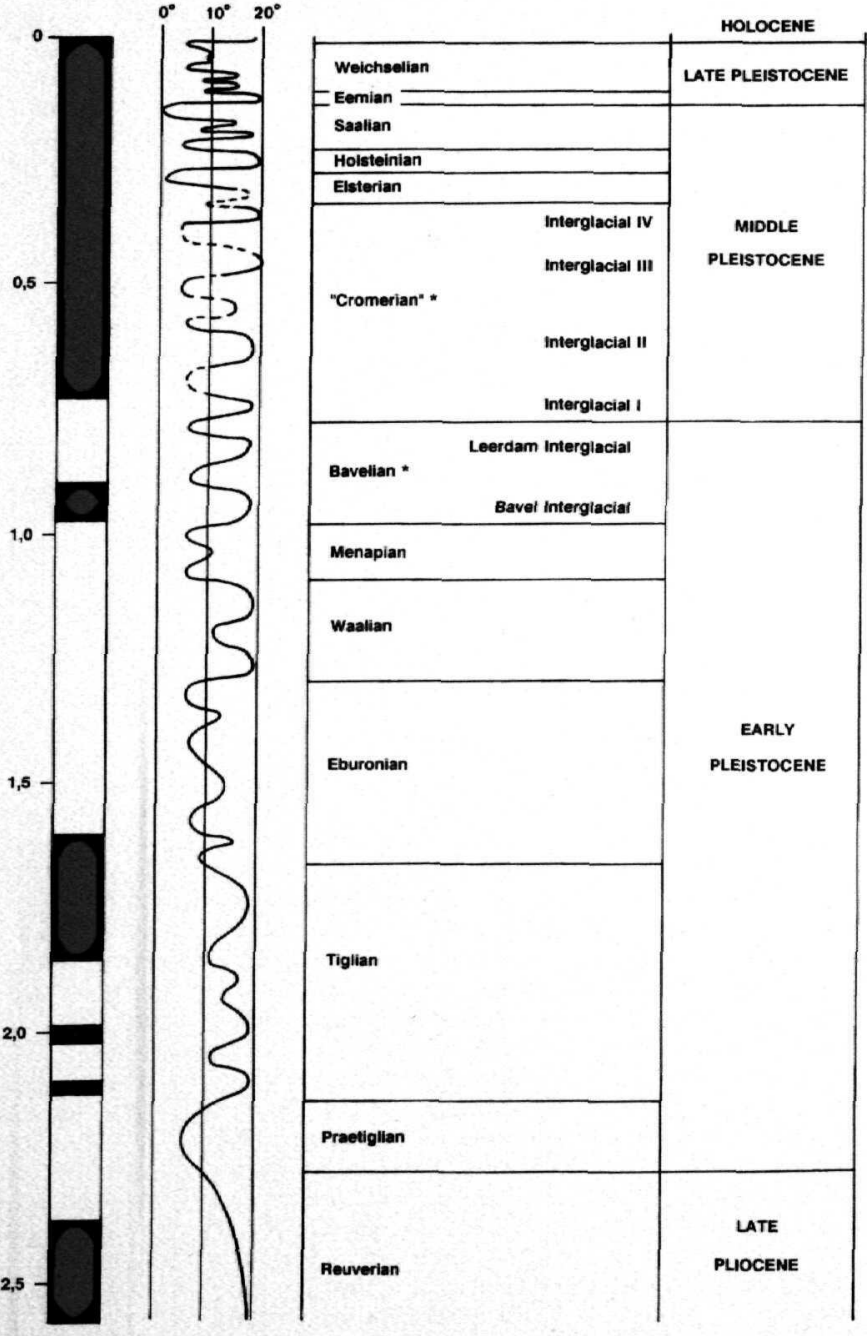

FIGURE 1. Climate curve for the Quaternary in the Netherlands (after Zagwijn 1985).

Age in million years.

Temperature in degrees $C$, estimated mean for July.

* includes several glacials and intergiacials. human agencies is sufficient to shift any burden of proof upon those who maintain the human origin of the stones; and this must not be done by a careful selection of picked specimens, but by a survey of the whole group.

The artefactual nature of 'primitive' assemblages has been an omnipresent issue ever since. In 1958 for instance, J. Desmond Clark's study of natural fractures of pebbles showed very convincingly (in the African context of 'Kafuan' industries in river valleys) that nature can make 'pebble tools': they are produced by a sharp 'follow through' blow, very unlikely under water, but possibly the result of a rock 
falling from above on to a wedged pebble (Clark 1958). These fractures can simulate artificial fracture to such a remarkable degree that these specimens would not be out of place in any 'Pebble Culture' context. His studies once again stressed that one cannot build a strong argument for early occupation on the basis of pieces with only a few negatives, selected out of riverlaid deposits. In fact, any analysis of early sites must take into account the whole range of natural conditions at the site that could produce artefact-like forms, as well as the geological setting of the find spot.

It is for these reasons that for instance Tuffreau (1987) does not accept the Ferme de Grâce (Somme) terrace material as evidence for Early Pleistocene occupation of northern France (contra Bourdier et al. 1974) or that Santonja \& Villa (1990) consider isolated pieces collected from Iberian river terraces as too rare and undiagnostic to prove human settlement in the Early Pleistocene.

In section 3 we evaluate some important early sites by the issues in the eolith debate. It is of course necessary to have a good knowledge of the assemblages and their context, either by a detailed site-publication or by first-hand knowledge. Unfortunately, only a small number of 'early' sites have been published in such a detail that evaluation of interpretations concerning the artefactual character of 'primitive' assemblages is possible. We start our review, therefore, with the evidence from central and northwestern Europe, where we have a first-hand knowledge of the relevant assemblages. The findings from that area are confronted with those from other areas in section 5.

\subsection{The chronological framework}

The classical subdivision of the Pleistocene is by the glacial-interglacial scheme, based on the extensions of glaciers in the Alpine area and northern Europe. Four different extensions were recorded in the Alpine area (Günz, Mindel, Riss and Würm) and in northern Europe only three (Elster, Saale and Weichsel). Glacigenic deposits were linked with cold intervals in which ice-sheets formed, separated from each other by warm-temperate intervals. Detailed investigations of pollen-bearing deposits in northwestern Europe yielded a rather complete record of the complex history of the vegetation there. Palaeobotanical data was transformed into palaeoclimatic information, making a terrestrial chronostratigraphical subdivision of the Pleistocene ( $c f$. Zagwijn 1985; see FIGURE 1), a scheme that has been the standard for northwestern Europe. The presence of well dated biostratigraphical marker species in the type area of the standard division offers the possibility to correlate sites from other areas to this subdivision.

Preliminary results of recent investigations in an open lignite mine at Schöningen near Helmstedt (Germany) and in the Don Basin (Russia) indicate, however, that the FIGURE 1 subdivision is incomplete. The Pleistocene sediments exposed in the Schöningen quarry date from the Elsterian to the Holocene and are rich in palaeobotanical, malacological and palaeontological information ( $c f$. Urban et al. 1991; Thieme et al. 1993). Studies of the Middle Pleistocene sequence indicate that - instead of two as in FIGURE 1 - there were at least three phases with a distinct, well developed interglacial vegetation between the Elsterian and the Saalian till.

Long sequences in the Don basin show at least five glacial-interglacial cycles in the timespan between the Brunhes/Matuyama boundary and the Oka (=Elsterian) glaciation (Kasansteva 1987). Correlation between the Don Basin and northwestern Europe, mainly on the base of mammal fauna associations, indicates that the northwestern standard subdivision is incomplete for the lower part of the Middle Pleistocene, i.e. in the first half of the 'Cromerian Complex'. The incompleteness of this continental subdivision is also apparent when comparing it with the oxygen isotope record, which counts 9 interglacial and 9 glacial phases within the Brunhes Epoch.

The oxygen isotope record, the most detailed subdivision of the Quaternary, is regarded as the timescale one should try to refer to. It is a global record, reflecting changes in the total amount of ice on land the world over, as there is little variation among cores taken from different areas. It is also a rather continuous record, providing a complete survey of the entire Quaternary. And it is a kind of 'Esperanto' record, easy to 'understand' for workers from various parts of the world, not bothered by the details and intricacies of the various regional subdivisions such as the northwestern one 


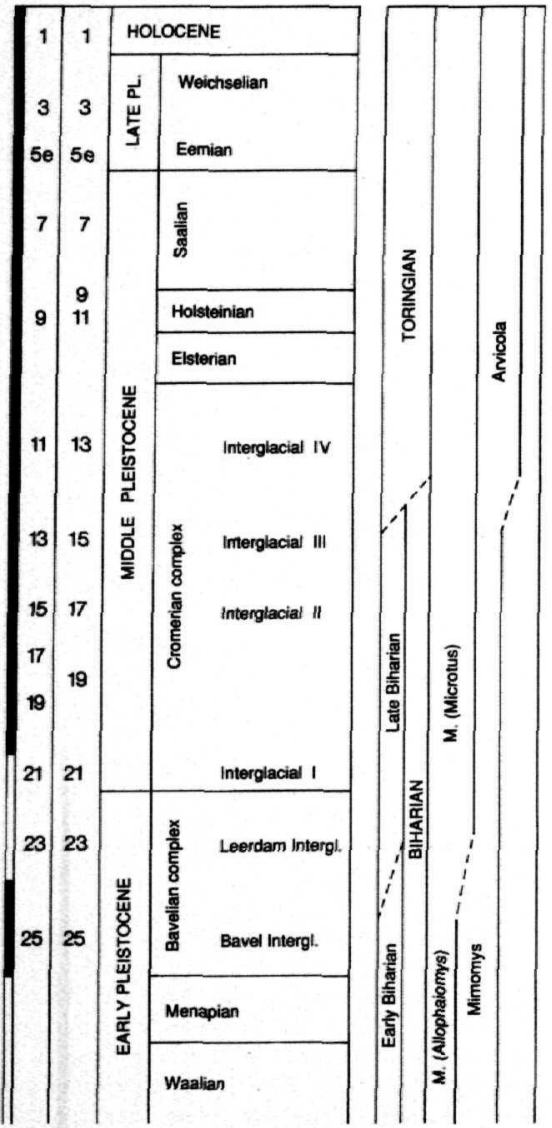

mentioned above. This 'user-friendliness' is certainly a very important factor in the increased usage of the deep-sea record for correlation-purposes. We must, however, not forget that correlation to the isotope stages is often mainly based on very simple 'counting' procedures, on the results of 'absolute' dating methods and on (often implicit) assumptions, for example that the maximum inland-ice extension corresponds to the highest $\mathrm{O}^{18}$ values. Unfortunately, terrestrial sections are dominated by gaps. Absolute dates, in many cases contradictory and inaccurate, should not be the only basis for a chronological correlation. Us-
Maastricht-Belvédère

Caune de L'Arago

Swanscombe, Hoxne, Bilzingsleben

Vértesszölös ?

Boxgrove, Sprimont, Miesenheim I.

Mauer, La Polledrara, Fontana

Ranuccio, Visogliano

Karlich G, Isernia

Venosa-Loreto

Prezletice, Stranska skabla

West Runton, Voigtstect

Kărlich $\mathrm{E}$

Kärlich C

Kärlich $\mathbf{B b}$

Kärlich Ba. Ferme de Gráce
Monte Peglia

Le Vallonét, Karlich A.

Untermassfeld

Venta Micena
FIGURE 2. Tentative correlation of small mammal biozonations and faunal assemblages to the northwest European subdivison of the Quaternary and to various oxygen isotope stages. ing the maximum ice extension for land-sea correlations poses problems as soon as one exchanges the narrow 'national' perspective for a broader 'European' one: the southernmost extension in Great Britain was the Anglian (= Elsterian), in the Netherlands it was the Saalian ice-cap and in the Don Basin it was the Don glaciation! These problems can lead to different correlations between the continental subdivision and the oxygen isotope record (see the two options presented in FIGURE 2).

Although not denying the enormous advantages of the deep-sea record over the continental divisions, we prefer the continental 


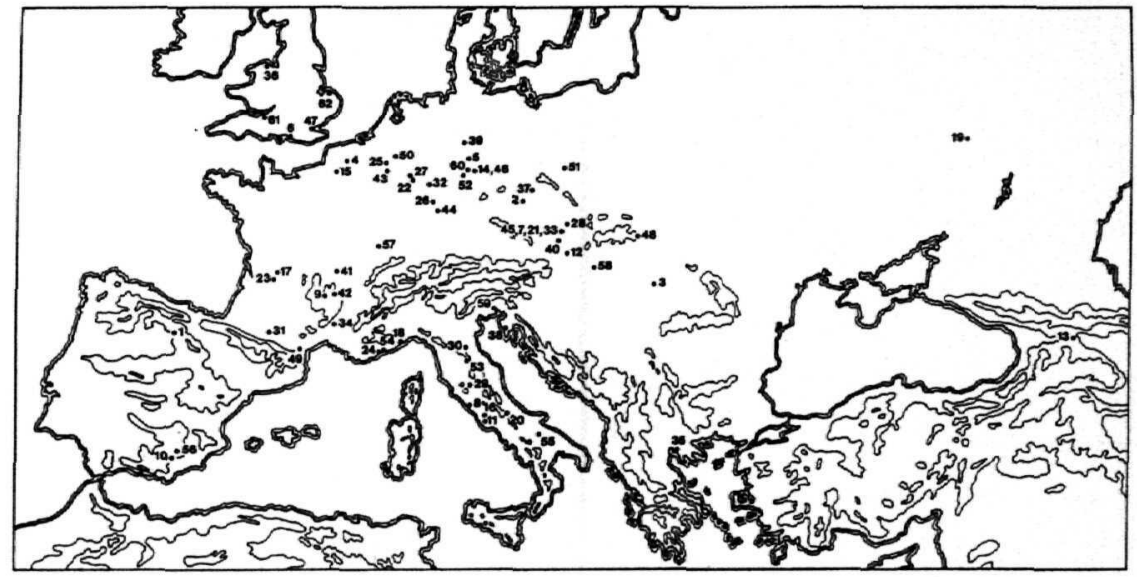

FiguRE 3. Map of sites mentioned in the text.

$\begin{array}{llrl}1 & \text { Atapuerca } & 17 & \text { Fontéchevade } \\ 2 & \text { Beroun } & 18 & \text { Grotte du Prince } \\ 3 & \text { Betfia } & 19 & \text { Ilynka } \\ 4 & \text { Biache-Saint-Vaast } & 20 & \text { Isernia } \\ 5 & \text { Bilzingsleben } & 21 & \text { Ivan } \\ 6 & \text { Boxgrove } & 22 & \text { Kärlich } \\ 7 & \text { Brno } & 23 & \text { La Chaise } \\ 8 & \text { Castel di Guido } & 24 & \text { Lazaret } \\ 9 & \text { Chilhac } & 25 & \text { Maastricht- } \\ 10 & \text { Cullar de Baza } & & \text { Belvédère } \\ 11 & \text { Cava Pompi } & 26 & \text { Mauer } \\ 12 & \text { Deutsch-Altenburg } & 27 & \text { Miesenheim } \\ 13 & \text { Dmanisi } & 28 & \text { Madec } \\ 14 & \text { Ehringsdorf } & 29 & \text { Monte Peglia } \\ 15 & \text { Ferme de Grâce } & 30 & \text { Monte Poggiolo } \\ 16 & \text { Fontana Ranuccio } & 31 & \text { Montmaurin }\end{array}$

subdivision of the Quaternary (FIGURE 1) as the basic framework for terrestrial correlation over the oxygen isotope record, as long as there are no reliable correlation methods (in other words: as long as the absolute dating methods are contradictory and inaccurate). Uncritical use of the deep sea stages creates a pseudocertainty that hides the basic stratigraphical problems inherent in all kinds of terrestrial correlations.

\section{The chronology of Quaternary mammalian fossil assemblages}

The use of palaeobotanical evidence for long-distance correlation to the terrestrial subdivisions is hampered by the absence of evolutionary

$\begin{array}{llll}\mathbf{3 2} & \text { Mosbach } & \mathbf{4 8} & \text { Tarkö } \\ \mathbf{3 3} & \text { Musov } & \mathbf{4 9} & \text { Tautavel } \\ \mathbf{3 4} & \text { Orgnac } & \mathbf{5 0} & \text { Tegelen } \\ \mathbf{3 5} & \text { Petralona } & \mathbf{5 1} & \text { Trzebnica } \\ \mathbf{3 6} & \text { Pontnewydd } & \mathbf{5 2} & \text { Untermassfeld } \\ \mathbf{3 7} & \text { Prezletice } & \mathbf{5 3} & \text { Val d'Arno } \\ 38 & \text { Sandalja } & \mathbf{5 4} & \text { Vallonet, Le } \\ 39 & \text { Schöningen } & \mathbf{5 5} & \text { Venosa Loreto } \\ \mathbf{4 0} & \text { Sedlesovice } & \mathbf{5 6} & \text { Venta Micena } \\ \mathbf{4 1} & \text { Sénèze } & \mathbf{5 7} & \text { Vergranne } \\ \mathbf{4 2} & \text { Soleilhac } & \mathbf{5 8} & \text { Vértesszöllös } \\ \mathbf{4 3} & \text { Sprimont } & \mathbf{5 9} & \text { Visogliano } \\ \mathbf{4 4} & \text { Steinheim } & \mathbf{6 0} & \text { Voigtstedt } \\ \mathbf{4 5} & \text { Stránská Skála } & \mathbf{6 1} & \text { Westbury-sub- } \\ \mathbf{4 6} & \text { Süssenborn } & & \text { Mendip } \\ \mathbf{4 7} & \text { Swanscombe } & \mathbf{6 2} & \text { West Runton }\end{array}$

trends in plants and by the inter-regional variations in characters of vegetation. Mammalian fossils are alternative important biostratigraphic indicators. Their use in dating and correlating deposits is based on the fact that most of the mammals have an extensive distribution area and that a number show a rapid evolution and/or migratory shifts within the Quaternary (cf. Lister 1992). The composition of the mammalian fauna has changed relatively fast during the Quaternary due to processes of evolution, extinction and migration of species; a number of mammal biozonations has been established by different authors. Some of these are based on the smaller mammal fauna, others on the larger or on both. 
Many palaeontologists work with the generally accepted biostratigraphical subdivision of the Quaternary based on the Arvicolidae succession, as proposed by Fejfar \& Heinrich (1981, in fact a modification of the Hungarian smaller mammal zonation established by Kretzoi (see e.g. Kretzoi 1965; Kretzoi \& Pécsi 1979; Van der Meulen 1973)). Fejfar \& Heinrich (1981) established three well defined biozones (stages in their terminology) for the Pleistocene: Villányian, Biharian and Toringian (see FIGURE 2). A biozonation on the basis of changes in the larger mammal fauna was constructed by Italian palaeontologists (Azzaroli et al. 1988). Their subdivision of Villafranchian and Galerian faunas is used in large parts of Europe and Asia despite the fact that the boundary between both biozones is poorly defined (below, page 496).

\subsection{The smaller mammals: Biharian-Toringian}

Biharian faunas differ from the preceeding Villányian ones by the occurrence of Microtus. The Villanyian faunas are recognized by the dominance of Mimomys, the Biharian faunas by the co-occurrence of Microtus and Mimomys and the Toringian 'Stage' by Arvicola-Microtus assemblages. The Biharian Stage is divided into two substages: the Early Biharian with Microtus (Allophaiomys) and the Late Biharian with Microtus (Microtus).

The transition from the Villányian to the Biharian in the Early Pleistocene corresponds more or less with the Tiglian/Eburonian transition. Faunas such as Tegelen (the Netherlands) belong to the Villanyian (FIGURE 2), while the Early Biharian comprises faunas such as Le Vallonet (France), Monte Peglia (Italy) and Betfia 2 (Romania).

The transition of Microtus (Allophaiomys) to Microtus (Microtus), marking the transition from the Early to the Late Biharian, dates to the early part of the Bavelian complex, roughly correlated to the Jaramillo.

Faunas such as West Runton, Stránská Skála, Prezletice (Czechia), Tarkö (Layer 16) (Hungary), Ilynka I-II and Ilynka IV (Russia) belang to the Late Biharian. The genus Mimomys is represented by only one species, the large Mimomys savini, in most of the late Biharian faunas. A second Mimomys, a smaller form often referred to Mimomys (Cseria) pusillus, occurs in some faunas. The Late Biharian cov- ers the later part of the Bavelian complex and most of the Cromerian complex, a time-span with at least five glacial/interglacial cycles as we know from the Don Basin sequence (Kasantseva 1987). The faunas with two Mimomys species date from the earlier part of that time-span, the faunas with only Mimomys savini from the later part.

A very important stratigraphical marker is the transition of Mimomys savini to Arvicola terrestris, which corresponds to the BiharianToringian boundary, in the second half of the Cromerian complex (van Kolfschoten 1990; Von Koenigswald \& van Kolfschoten in press). Since the most primitive representative of the genus Arvicola, Arvicola terrestris cantiana (often cited as e.g. Arvicola cantiana or Arvicola mosbachensis), is known in northwestern Europe from Cromerian Interglacial IV deposits (van Kolfschoten 1990), the transition took place before Interglacial IV of the Cromerian Complex. Arvicola appears for the first time in the Kärlich section in the fauna from Kärlich $\mathrm{G}$. The heavy-mineral association of the Kärlich $G$ deposits and the mammal fauna indicate a Cromerian Interglacial III or a (beginning of) Interglacial IV age (van Kolfschoten \& Turner in press; Von Koenigswald \& van Kolfschoten in press). The MimomysArvicola transition has been documented in western (Chaline 1986), central (Fejfar \& Heinrich 1981) and eastern Europe (Terzea in press). In northwestern Europe the transition took place in the second half of the Cromerian Complex. This seems to have been the case in other areas too, as for instance shown by the occurrence of Arvicola terrestris before the Elsterian in Central Europe (Terzea in press) and the occurrence of very advanced Mimomys savini in faunas from the Don Basin, dated to the second interglacial before the Oka-Elsterian glaciation (Kasansteva 1987; van Kolfschoten in prep.). It is to be expected that there was an asynchronicity within the regional transition from Mimomys to Arvicola, but such transgressions fall outside the chronological resolution of our present dating methods for this time-range.

A problem in this respect is the age of the Arvicola fauna from Isernia (Italy), supposed to be late Early Pleistocene on the basis of radiometric dates for crystals from the site matrix and some palaeomagnetic data (Coltorti et al. 1982; McPherron \& Schmidt 1983). Isernia 
has yielded fossil remains of Arvicola terrestris cantiana (assigned to the junior synonym Arvicola mosbachensis by Sala 1983; Coltorti et al. 1982). A study of the material, including that sampled in the period after 1982, allowed the second author to characterize the finds of Isernia as a primitive population of the genus Arvicola. Only $80 \%$ of the molars (only a few of them are juvenile) are rootless, whereas $20 \%$ show indications for root formation but are still rootless. The fauna with Arvicola, Elephas (P.) antiquus, Stephanorhinus hundsheimensis and without Mimomys savini, Mimomys pusillus and Microtus (Allophaiomys) sp. suggests a Middle Pleistocene age, as it is comparable to central European faunas as Mosbach and Mauer ( $c f$. Sala \& Fortelius 1993). One could accept a late Early Pleistocene age for Isernia only by suggesting an earlier occurrence of Arvicola in Italy, in a more or less isolated area of Europe. This is not a plausible argument, however, as there are no indications of a barrier isolating the mammalian faunas in Italy from those of central and western Europe during the Pleistocene. On the contrary, the abundant similarities in Early, Middle and Late Pleistocene faunas of Italy and eastern, central and western Europe show a general and almost continuous faunal exchange between these areas during the Quaternary (Von Koenigswald \& van Kolfschoten in press). Therefore we seriously question the palaeomagnetic and radiometric dates for the Isernia site, and do not believe that Isernia is as old as 700,000 years BP.

Toringian faunas can be divided into two groups: an older one with Arvicola terrestris cantiana co-occurs with so-called relict species (such as Talpa minor, Trogontherium cuvieri) and a younger group with Arvicola terrestris ssp. A and B, co-occurs with a modern smaller mammal fauna (see van Kolfschoten 1990). The first group comprises faunas such as Miesenheim I, Kärlich G, Mauer (Germany), Boxgrove, Westbury-sub-Mendip (Great Britain), Sprimont (Belle Roche) (Belgium), Tarkö (Hungary) with Arvicola terrestris cantiana together with Sorex (Drepanosorex) sp. and Pliomys episcopalis and a number of faunas e.g. Swanscombe (Great Britain), Bilzingsleben (Germany) younger in age and without Sorex (Drepanosorex) and Pliomys episcopalis.

Since the early Saalian, thinning of the convex sides of the dentine triangles has resulted in changes in the relative thickness of the enamel band of the Arvicola molars. This development can be used for stratigraphical correlations of younger, i.e. post-'Holsteinian' faunas, such as those from Caune de l'Arago at Tautavel (Desclaux 1992a; 1992b), MaastrichtBelvédère and Weimar-Ehringsdorf ( $c f$. van Kolfschoten 1990).

\subsection{The larger mammals: Villafranchian-Galerian}

The widely used Italian biochronology, with a subdivision in Villafranchian and Galerian faunas, is mainly based on changes in the larger mammal fauna. The Villafranchian, starting about 3 million years ago, covers part of the Pliocene and the Early Pleistocene. It has been sub-divided into an early, a middle and a late phase, a subdivison refined by Azzaroli (1977), who divided the Villafranchian faunas into six more or less well-defined faunal units. The beginning of the Villafranchian itself, of some of its units and its end are characterized by pronounced dispersal events (Azzaroli et al. 1988; Sala et al. 1992). Azzaroli et al. (1988) state that the Villafranchian-Galerian transition (the end-Villafranchian event, 1.0-0.9 million years ago) saw a complete faunal turnover, with massive extinctions and new, previously unknown adaptations. Late Villafranchian taxa such as Eucladoceros, Dama nestii, Leptobos etruscus, Sus strozzii and Archidiskodon meridionalis became extinct, whereas many taxa (Megaceros, Soergelia sp., Praeavibos priscus, Bison schaetensacki, Equus süssenbornensis, Ursus deningeri) appear during the Early Galerian.

The transition of the late Villafranchian to the Galerian did not take place at once; according to Azzaroli et al. (1988), the transitional phase was of (geologically) short duration because only a few sites have 'naturally mixed' assemblages - an assumption partially based on the inferred Early Pleistocene age of Isernia. They assign a late Matuyama age to the Isernia fauna, and hence infer that faunas from normally magnetized deposits (such as the faunas from West Runton and Voigtstedt) have to be correlated with the Jaramillo event. In such a scenario the Villafranchian/Galerian faunal shift indeed seems both very pronounced and relatively abrupt. In our opinion the faunas from Isernia, West Runton and Voigtstedt are of Middle Pleistocene age, which means that 
the faunal turn-over could have taken place more gradually. For us the 'faunal watershed' is simply the result of a giant temporal collapse, caused by an accumulation of correlation errors.

This interpretation is confirmed by the fauna from Venta Micena, dated at around 1.2 million years ago yet already containing several Galerian immigrants (Megaloceros, Praeovibos, Soergelia and Bison) (Agusti et al. 1987). The end-Villafranchian 'event' in the sense of e.g. Azzaroli et al. (1988) therefore probably has a long stratigraphical range, which necessitates a re-definition of the late VillafranchianGalerian boundary. At the current state of knowledge the terms late Villafranchian or Galerian are of little biostratigraphical value.

\section{The earliest occupation of central and northwestern Europe}

\subsection{The Early Pleistocene}

The pseudo-artefact problem is especially apparent in central European sites where (amateur) archaeologists sampled huge amounts of gravels and came up with primitive looking 'choppers' and 'chopping-tools'. A good example is the Beroun site, near Prague (Fridrich 1991), where about 80 artefacts were collected from the top of Early Pleistocene river gravels, exposed over an area of about 2000 sq. m. Two overlying levels yielded 10 more 'items of industry'. The 80 rolled 'artefacts', mostly 'sidechoppers' with only a few negatives, were collected from the gravel surface 'after rain'. According to Fridrich (1991: 111), the assemblage 'includes choppers, bifaces, proto-bifaces, picks, cleavers, polyhedrons, subspheroids, representing Acheulean s.I., comparable to the African finds'. The finds, both those published and those displayed in the Prague National Museum, are clearly in the range of what can be collected from natural gravel deposits; they are not acceptable evidence of Early Pleistocene occupation (see Kozlowski 1991 for a comparable interpretation).

The same applies to the Musov and Ivan assemblages, described by Valoch (1991). Both sites, approximately $40 \mathrm{~km}$ south of Brno, were visited by an amateur archaeologist, who collected hundreds of 'choppers' and 'choppingtools' from re-worked Miocene deposits, present on top of Early or early Middle Pleistocene deposits. As in Beroun, we are dealing with a selection from thousands and thousands of non-modified pebbles. The 'artefacts' have in general only a few irregular negatives, and almost all 'chopping-tools' display completely blunted 'working edges'.

Comparable arguments apply to other Early Pleistocene sites in Moravia (Brno-Cernovice, with one good flake though, not recovered in situ, and Brno-Cernovice Kopec). A polyhedron from Mladec cave, found in a calcite layer covering the Early Pleistocene sediments there, has no chronological context.

Early Pleistocene artefacts from the river deposits exposed in the Kärlich section (Kärlich A) were found and published by Würges (1986). Three 'pebble tools' were flaked on one surface only. The 'best' piece is a pebble, broken along a quartz vein, with two negatives. The pieces fall in the range of naturally produced 'artefacts' ( $c f$. Clark 1958) and they were not recovered in a controlled situation; at best they are to be treated as typical incertofacts, a category of pieces of which the artificial character can neither be established with certainty nor excluded. The same applies to the trachytic tuff core from Kärlich $\mathrm{Ba}$, recovered outside stratigraphical context (Vollbrecht 1992).

\subsection{The Middle Pleistocene}

Most archaeology textbooks mention the Czech site of Prezletice as one of the earliest sites in Europe. Palaeomagnetic and faunal studies (a fauna with Mimomys) have placed it in the beginning of the Middle Pleistocene. The find of what was once thought to be a human molar (now an Ursus sp. molar, see Fridrich 1989: 29) initiated archaeological excavations (19691985) that focussed on sediments deposited near an ancient lake at the foot of a lydite massif. It yielded 4 horizons bearing 'artefacts' produced out of locally occurring lydite debris. Fridrich (1989: passim) himself stressed that it was very difficult to differentiate between 'flaking and natural fracturing of raw material in lydite débris.... There is complete lack of flakes or, on the contrary, of primitive cores ... treatment of raw material, manufacturing of half-products and their waste fracturing occurred along hidden cleavages in raw material. There are not typical traces after working, namely bulbs, therefore the possibility to recognize and differentiate between artificial working and natural fracturing is ex- 
tremely low' (emphasis added). Nevertheless, the drawings in Fridrich (1989) display many negatives of flaking and retouch on the 'proto-bifaces', 'picks' and other artefacts recognized among the lydite debris, but there is a big discrepancy between the drawings and the photos of the objects. Likewise, the pieces on display in the Prague National Museum in our opinion do not show any convincing traces of human interference.

The site of Stránská skála, near Brno, yielded a Late Biharian fauna comparable to Prezletice. In 1968 Valoch described some 'flakes of hornstone suggestive of human workmanship' recovered from early Middle Pleistocene screedeposits in the 1910-1945 excavations. He thought the site was problematic because 'Weathered nodules, often naturally cracked and broken, occur in the debris in considerable quantity, making it difficult to identify those chips that could have been flaked and utilized by man' (Musil \& Valoch 1968: 538; also Valoch 1972). Since then new palaeontological fieldwork has yielded more finds, which led Valoch to give up his doubts about the artificial character of the stone assemblage selected from the slope deposits and from within two small caves in the Stránská skála exposure (Valoch 1987). Three dozen artefacts have been identified by him. These hornstone fragments display no clear traces of human workmanship: there are virtually no bulbs (only three observed), no clear negatives or ripples. While visiting the site with Dr Valoch the first author could pick up hornstone fragments from the scree-section, which is full of hornstone debris; one wonders what the ratio between 'discarded' and 'accepted' pieces within this deposit actually was.

On these grounds, arguments concerning context and attributes of the finds, the site cannot be considered as proof for an early Middle Pleistocene occupation of Moravia. We support Valoch's earlier doubts concerning the artefactual character of the assemblage.

The first good evidence from this part of central Europe comes from Sedlesovice near Znojmo, where a quartz artefact was discovered in a loess profile, in the fossil soil PK VI ('Holstein'; see Valoch 1984). The first finds from Poland (Trzebnica) are from around this time horizon too (Burdukiewicz \& Winnicki 1988; 1989; also Kozlowski 1992).
For the western part of central Europe, Würges (1986) claims earlier finds from the top of the Kärlich Mosel gravels (Kärlich Bb). Over an area of $40 \times 40 \mathrm{~m}$ Würges collected a set of 8 quartzite pieces, some from the top of the gravel deposits, some from the base of the gravels, having slid downslope. Some of the pieces are heavily rounded, others less so. It took Würges more than one year to assemble this set, very clearly a selection of pieces, whose number is infinitesimally small compared to the whole. The 'primitive' morphology of the pieces and their context lead us to doubt the artefactual character of these, and to interpret them in the same way as Tuffreau (1987) did with Ferme de Grâce material.

In our opinion western central Europe has its earliest solid evidence for human occupation around the Cromer IV interglacial (Oxygen Isotope Stage 11 to 13 ? (respectively $362,000-423,000$ and $478,000-524,000$ years $\mathrm{BP})$ ), in the form of the finds from Kärlich G, the primary-context Miesenheim I site and the Mauer mandible, all associated with Arvicola terrestris cantiana faunas. From that time-period onwards there are more primary context sites in central Europe, both from temperate and from colder, dryer settings (Roebroeks et al. 1992; Gamble 1993).

In the northwest region, the earliest solid traces of occupation are more or less contemporaneous with the Miesenheim I site, for example the well-preserved find scatters at Boxgrove in southern England (Roberts 1986; 1990) and the earliest sites in the Somme valley of northern France (Tuffreau 1987). The Boxgrove site is tentatively correlated to Oxygen Isotope Stage 13.

Independent of their correlations to the deep-sea record, the earliest sites from both central and northwest Europe fall in the Arvicola terrestris cantiana range. From that period onwards, there is a large number of welldocumented primary context sites in the northwest-central region, with conjoining knapping debris preserved in fine-grained fluvial and aeolian deposits ( $c f$. Roebroeks et al. 1992).

\section{Other regions, comparable results?}

Like those in the northern regions, Iberian river terraces have yielded isolated pieces, whose human manufacture or precise age have been doubted by various researchers (Raposo 1985; 
Santonja \& Villa 1990), who place the oldest sites from Iberia at the beginning of the Middle Pleistocene, though such traces are very rare. Some of the best sites are in the GuadixBaza depression (Granada), famous for its rich Early Pleistocene mammalian faunas. The oldest site, Cullar de Baza, has yielded only a few pieces (six flakes and two choppers), in association with a Middle Pleistocene fauna. The faunal list varies from author to author ( $c f$. Santonja 1992: 57); on biostratigraphical grounds the site is very probably contemporaneous with the earliest sites from the northwest-central region. If the five artefacts recently reported from Atapuerca TD4 (Carbonell \& Rodriguez 1994) indeed are man-made objects, they would be older than the other archaeological sites reviewed so far, as they are associated with a Mimomys fauna (Gil \& Sese 1991). The handaxes reported from Atapuerca TD6 are from a later period, when Pliomys episcopalis disappears (Aguirre 1991), possibly Stage 13, according to the excavators (Carbonell \& Rodriguez 1994).

Italy's settlement history ( $c f$. Mussi 1992) shows no unambiguous indications for an Early Pleistocene occupation. A number of the 'old' Italian sites are surface sites, where a 'primitive' morphology of artefacts has led some archaeologists to infer a high age. In view of those correlation problems, the site of Monte Poggiolo does not provide very firm evidence for Early Pleistocene occupation, though the preliminary results of the palaeomagnetic studies indicate that it deserves our attention as a possible candidate (Gagnepain et al. 1992). All unquestionable archaeological sites with solid dating evidence date from well into the Middle Pleistocene, and those with abundant faunal remains are more or less comparable in age to the Boxgrove and Miesenheim I sites in the north: Fontana Ranuccio (with hominid remains), Visogliano (human fossils too) and probably also Venosa-Loreto. As already explained, in our opinion, Isernia falls into this time range too (pages 494-5, above).

In Croatia, the bone breccia of the Sandalja I cave yielded an incisor, once considered to be a hominid fossil (Malez 1976 vs. Cook et al. 1982) and one small and primitive 'chopper', a single find too undiagnostic to provide a firm ground for Early Pleistocene occupation of former Yugoslavia.
So while the regions discussed as yet have not yielded solid proof of human occupation prior to the Middle Pleistocene, there are some sites in southern France that seem to be older: a group of sites in the Massif Central, and the famous cave-site of Le Vallonet.

The Massif Central has a large number of sites with rich Early Pleistocene faunas, recovered in a good stratigraphical context. The stone assemblages collected from some of these sites ( $c f$. Bonifay 1991) consist in general of small series, selected out of natural pieces occurring in often coarse-grained deposits. The short communications on these assemblages do not deal with the problems of differentiating between natural and humanly modified pieces. In many ways an exception is the Chilhac III site, excavated by Chavaillon (1991; also Guth \& Chavaillon 1985) in order to test Guth's earlier assessments of the site. Among the split pebbles and rocks in the Chilhac III deposits, Chavaillon could identify 46 indisputable artefacts. The age of these artefacts is uncertain for the time being, for reasons elaborated by Chavaillon (1991). In his words 'Tout est possible pour Chilhac III (1991: 87).

Another well-known Massif Central site is Soleilhac. Unfortunately its lithic assemblage has not been published in detail. According to Bonifay, we are dealing with a small assemblage of primitive technology. The quartz pebbles have been more 'shattered' ('brisés') than flaked, whereas the majority of the 'objets de grande taille en basalte' have been made out of natural fragments (Bonifay 1987: 13). From the description, it is clear that the excavators selected basalt objects (with 'rostrocarinate' forms) out of other non-modified basalt fragments. More important is that the Soleilhac fauna (with Arvicola, Elephas (P.) antiquus and Hippopotamus: Bonifay 1991) could fit very well into the late Cromerian faunas mentioned above. Awaiting the results of further study of the chronology of the site and detailed publication of the stone finds, we see no good reason to think Soleilhac provides an Early or early Middle Pleistocene hominid occupation.

Le Vallonet has been well published, in a way that allows a detailed evaluation of the artefacts. The cave has yielded a rich fauna (with Microtus [Allophaiomys] pliocaenicus) and a small lithic assemblage, recovered from 
before 500,000 years ago

small series of isolated pieces selected from a natural pebble background

disturbed context (coarse matrix)

contested 'primitive' assemblages

no human remains at all after 500,000 years ago

large collections from excavated knapping floors with conjoinable material

primary context sites (finegrained matrix)

uncontested Acheulean and non-Acheulean industries

TABLE 1. Schematic differences within the European Palaeolithic record between the period before and after about 500,000 years ago.

sediments of 'Jaramillo' age (age assessments by means of biostratigraphy, absolute dating (ESR) and palaeomagnetic studies (see various contributions in L'Anthropologie 92 (1988); but also Bonifay 1991: 74-5). The lithic assemblage comes from stratigraphic Unit III (layers B1, B2, C), loamy sands with many angular rocks and pebbles. These sediments are to a large extent re-worked from the Roquebrune Miocene conglomerate deposits present above the cave. The sand and rock/pebble fraction flowed into the Vallonet cave through chimneys and fissures. After Unit III was formed, the sediments were subjected to intensive geochemical weathering, leading to all kinds of 'déformation' of the rocks and pebbles in the matrix: 'Les cailloux et les galets de ces niveaux sont souvent craquelés avec déplacements de fragments' (De Lumley 1988: 416). Excavations in the stony deposits yielded in total 70 pieces from a 'fairly underdeveloped stone tool industry'. Fifty-nine of these are interpreted as intentionally modified. Virtually all artefacts were made from limestone pebbles from the Roquebrune Miocene conglomerate. The artefacts consist primarily of flaked pebbles, among which 'percussion tools', 'pebbles with a single convex chip' are the most common (13 examples). Well represented are pebbles 'with a single concave chip' (primary choppers, 8 examples), but these are badly fragmented. Pebble tools (choppers, chopping-tools and atypical chopping-tools) are present (10 examples), though not standardized and mostly of mediocre quality. The dorsal surface of half of the 26 flakes consists of $100 \%$ cortex, only 5 flakes have no cortex at all. The majority of the flakes have no butt or a 'reduced' one.

The Le Vallonet limestone pieces, partially decarbonated, are occasionally extremely frag- ile. Some of the rocks and pebbles were fractured, 'craquelés' by chemical weathering. The non-modified as well as the flaked pebbles and rocks in the Unit III matrix display several kinds of surface modifications, with ridges and protruding parts smoothed, or displaying a glossy surface polish. This applies to about $60 \%$ of the natural stones in the matrix. Comparable phenomena are present on the 'flaked' pieces: 'Les pièces de I'industrie lithique découvertes dans le remplissage du Pléistocène inférieur de l'ensemble III n'échappent pas à cette règle générale: un important émoussé adoucit parfois les arêtes et oblitère le modelé des enlèvements. La surface de ces pièces présente souvent un lustrage caractéristique' (De Lumley et al. 1988: 505).

It is clear that the lithic assemblage from Le Vallonet is a selection of 'primitive' pieces picked out from a matrix rich in rocks and pebbles derived from Miocene deposits (see the photos of the Unit III sediments in De Lumley et al. 1988: figures 1-7). Their characteristics suggest that we are dealing with an assemblage that was not modified by human agents, and instead displays all the characteristics of a selection out of a natural deposit.

\section{Implications}

By our reading of the evidence, there is a difference between the European 'archaeological' record from before the Arvicola terrestris cantiana time-range (for convenience' sake here: from about 500,000 years ago) and the later one ( $c f$. TABLE 1; also Dennell 1983 for a comparable interpretation). Before 500,000, virtually all finds come from a disturbed, coarse matrix, afterwards we have primary context sites in fine-grained deposits. The assemblages dating from before 500,000 are virtually all the 
result of selection of isolated pieces from natural deposits, younger ones are often excavated from knapping floors.

There are two basic ways to interpret these differences. The pre-500,000 finds could reflect the sparse traces of intermittent occupation of Europe, substantial colonization of Europe taking place from about 500,000 onwards ( $c f$. Turner 1992). Nevertheless, the differences in geological context and recovery procedures between pre- and post-500,000 sites are problems to be explained by those adhering to this long chronology.

In view of the attributes of the 'artefacts' and contexts of the pre-500,000 sites, we instead interpret these differences as no undisputable proof for human occupation of Europe prior to about 500,000 years ago. The first primary context sites with good archaeological evidence date from a later period within the Middle Pleistocene, possibly from about Stage 13 onwards.

Our scenario has several advantages. A first one is that it is very easy to falsify. The find of only one Early Pleistocene site of primary context in Europe would disprove it, and one would have to conclude that before about 500,000 occupation existed (but was largely intermittent). New studies of some of the sites mentioned in our short survey could lead to such a result.

A further advantage is that our short chronology is supported by a body of data independent of arguments concerning stone tools: the chronological distribution of human remains. The discrepancy between the inferred high age of the earliest European artefacts and the relatively recent date for the earliest European hominid fossils, the Mauer lower jaw and the human remains from Fontana Ranuccio and (possibly) Visogliano has been a conspicious problem in the search for the earliest Europeans. From the 'Mauer' time period onwards we have Middle Pleistocene human remains all over Europe: Arago, Atapuerca, Biache-SaintVaast, Bilzingsleben, Cava Pompi, Castel di Guido, La Chaise, Ehringsdorf, Fontana Ranuccio, Fontéchevade, Grotte du Prince, Lazaret, Mauer, Montmaurin, Orgnac III, Petralona, Pontnewydd, Steinheim, Swanscombe, Venose, Vergranne, Vértesszöllös and Visogliano, to mention them in alphabetical order (cf. Cook et al. 1982). The recently discov- ered tibia from Boxgrove, a site with one of the earliest Arvicola terrestris cantiana faunas, of course fits very well in our scenario too (Roberts et al. 1994; see also Gamble 1994).

From the long period before the Arvicola terrestris cantiana range we do not have a single (uncontested!) tooth yet, despite huge amounts of other mammalian fossils. Absence of evidence is of course no evidence of absence, and negative evidence has rarely proved durable in archaeology. But absence of exposures of older deposits is not a good counter-argument here. At a large number of palaeontological sites, early Middle and/or Early Pleistocene faunas are recovered from fine-grained deposits. Some of these have been under observation for many decades or even centuries, yielding huge amounts of faunal remains: for instance the Tegelen pits in the Netherlands, Untermassfeld, Voigtstedt and Süssenborn in Germany, West Runton (England), Sénèze (France), Deutsch Altenburg in Austria and the Val d'Arno exposures in Italy. Europe is without any doubt the most heavily researched part of the Old World, with a high-quality record to which many hundreds of workers have contributed over a period of one-and-a-half centuries.

In our scenario Europe is extremely 'marginal', late in time as compared to for instance the Asian evidence as that stands now. The human spread out of Africa went eastwards first, via Ubeidiya (Israel) and Dmanisi (Georgia; see Dzaparidze et al. 1989), and hominids were present in the eastern parts of Asia at the end of the Early Pleistocene, at around $1,000,000$ to 800,000 (Schick \& Zhuan 1993; even earlier, if one accepts the Swisher et al. (1994) dates). Europe was occupied later. Soon after we see the first undisputable traces, humans are virtually 'everywhere' in Europe (with as notable and interesting exceptions the Russian plains and Scandinavia).

At issue is not only whether the first Europeans arrived much earlier than 500,000. What, if any, ecological, climatical or social factors were triggering the occupation at about 500,000 , or, formulated in another way, what kept hominids out of Europe before 500,000? Some avenues worth exploring may be developments in the social domain, such as the emergence of dispersed mating networks, neural developments associated with brain expansion and differences in the character of the 
Lower as opposed to the Middle Pleistocene glacial-interglacial cycles ( $c f$. Zagwijn 1992; see also Gamble 1993).

In our scenario, the 500,000 'wave' represents the first occupation, virtually synchronous throughout Europe south of the ice sheets. In this view Europe does not seem to have presented big problems for the first occupants, be it perhaps in the northern- and easternmost parts. This image of a swift occupation can very well be the result of the low chronological resolution of our dating methods for the Middle Pleistocene (as compared to ${ }^{14} \mathrm{C}$, whose resolution allows our American colleagues to infer that Palaeoindians colonized the entire New World in just a few centuries: Meltzer 1993). These analogues yield fascinating thought-experiments that have the additional advantage of moving our field into the domain of other disciplines studying the migration of mammal species ( $c f$. Gamble 1993).

While those adhering to (various forms of) a long chronology can make the case for a very gradual adaptation by 'Out of Africans' to the wide range of European habitats, our short chronology supports another view, a rather fast (within the time resolution limits) adaptation, once they are in this cul de sac of the Eurasian

\section{References}

ACKERMAN, S. 1989. European prehistory gets even alder, Science 246: 28-30.

AGUIRRE, E. 1991. Les premiers peuplements humains de la Péninsule Tbérique, in Bonifay \& Vandermeersch (1991): 143-50.

Agust, S. MOYÀ-SOLÀ \& J. PONS-MOYÀ. 1987. La sucesion de Mamiferos en el Pleistoceno inferior de Europa: proposicion de una nueva escala bioestratigrafica, Paleontologia; Evolucio, Memoria Especial 1: 28795.

Azzaroli, A. 1977. The Villafranchian stage in Italy and the Plio-Pleistocene boundary, Giornale di Geologia 41: $61-79$.

AzZaroli, A., C. De Giuli, G. Ficcarkili \& D. Torre. 1988. Late Pliocene to Mid-Pleistocene mammals in Eurasia: faunal succession and dispersal events, Palaeogeography, Palaeoclimatology, Palaeoecology 66: 77-100.

BONIFAY, E. 1987. Soleilhac 1987. Rapport de fouilles. Marseille: Laboratoire de Géologie du Quaternaire.

1991. Les premiers industries du Sud-Est de la France et du Massif-Central, in Bonifay \& Vandermeersch (1991): 63-80.

Bonifay, E. \& B. VANDERMERRSCH (ed.). 1991. Les Premiers Européens. Paris: Editions du C.T.H.S.

Boule, M. 1921. Les Hommes Fossiles. Eléments de paléontologie humaine. Paris: Masson.

Bourdier, F., J. Chaline, A.V. MunaUt \& J.J. PUISSEgur. 1974. La très haute nappe alluviale de la Somme, continent that we call Europe. It is for such reasons that we need to discuss the empirical values and implications of the various long and shorter chronologies. We hope that our paper can contribute to such an 'updating' of the discussion on the first 'Europeans'.

Acknowledgements. A first version of this paper was written for a European Science Foundation (ESF) Workshop on The Earliest Occupation of Europe, held at Tautavel (France), November 1993, and hosted by H. De Lumley. That meeting was organized by the ESF Network on The Palaeolithic Occupation of Europe: G. Bosinski (chairman - Neuwied, Germany), W. Roebroeks (scientific secretary - Leiden, The Netherlands), C. Farizy (Paris, France), C. Gamble (Southampton, United Kingdom), L. Larsson (Lund, Sweden), M. Mussi (Rome, Italy), N. Praslov (St. Peterburg, Russia), L. Raposo (Lisbon, Portugal), M. Santonja (Salamanca, Spain) and A. Tuffreau (Lille, France). The members of the Network committee made valuable remarks on the content of our paper. We are further very grateful to F.C. Howell (Berkeley), A. Turner (Liverpool) and R. Dennell (Sheffield) for their detailed comments on an earlier draft of the paper, while the first author wishes to acknowledge his gratitude towards $\mathrm{K}$. Valoch, for his hospitality during his visit to Brmo. The proceedings of the Tautavel meeting are being edited by the present authors, in cooperation with G. Bosinski, and are scheduled to appear in the course of 1994.

The research was supported by the Netherlands Organisation for Scientific Research and the Royal Netherlands Academy of Arts and Sciences.

Bulletin de l'Association Française pour l'Etude du Quaternaire 11: 137-43.

BURDUKIEWICZ, J.M. \& J. WINNICKI. 1988. Trzebnica Najstarsze Slady Obecnosci Czlowieka na Ziemiach Polskich. Towarzystwo Milosników Ziemi Trzebnickiej.

1989. Nowe Materialy Paleolitu Dolnego Z Trzebnicy. Woj. Wroclaw, Silesia Antiqua 31: 9-17.

CARBONELL, E. \& X.P. RODRIGUEZ. 1994. Early Middle Pleistocene deposits and artefacts in the Gran Dolina site (TD4) of the 'Sierra de Atapuerca' (Burgos, Spain), Journal of Human Evolution 26: 291-311.

CHALINE, J. 1986. Continental faunal units of the Plio-Pleistocene of France, Memorie della Società Geologic Italiana 31: 175-83.

CHAMAGNE, B. 1988. Environnement géologique de la grotte du Vallonet (Roquebrune-Cap-Martin), L'Anthro. pologie 92: 399-406.

CHAvanloN, J. 1991. Les ensembles lithiques de Chilhac III (Haute Loire): typologie, situation stratigraphique et analyse critique et comparative, in Bonifay \& Vandermeersch (1991): 81-91.

CLARK, J.D. 1958. The natural fracture of pebbles from the Batoka Gorge, Northern Rhodesia, and its bearing on the Kafuan industries of Africa, Proceedings of the Prehistoric Society 24: 64-77.

Coltorti, M., M. CRemaschi, M.C. Delitala et al. 1981. Reversed magnetic polarity at an early Lower Palaeolithic site in Central Italy, Nature 300: 173-6. 
COOK, J., C.B. Stringer, A.P. CurRant, H.P. SchWarCZ \& A.G. WinTLE. 1982. A review of the chronology of the European Middle Pleistocene hominid record, Yearbook of Physical Anthropology 25: 19-65.

DELson, E. 1989. Oldest Eurasian stone tools, Nature 340: 96.

DENNELL, R. 1983. European econamic prehistory. A new approach. London: Academic Press.

DESClauX, E. 1992a. Les petits vertèbres à la Caune de l'Arago (Tautavel, Pyrénées Orientales). Paléontologie, paléoécologie, taphonomie. Thèse de Doctorat. Paris: M.N.H.N.

1992b. Les petits vertèbres de la Caune de l'Arago à Tautavel, Bulletin du Musée d'Anthropologie préhistorique de Monaco 35: 35-64.

DZAPARIDZE, V., G. BOSINSKI, T. BUGIANISVILI et al. 1989. Der altpaläolithische Fundplatz Dmanisi in Georgien (Kaukasus), Jahrbuch des Römisch-Germanischen Zentralmuseums Mainz: 67-116.

FEJFAR, O. \& W.D. HEINRICH. 1981. Zur biostratigraphischen Abgrenzung und Gliederung des kontinentalen Quartärs in Europa an Hand von Arvicoliden (Rodentia, Mammalia), Ecologae Geologicae Helveticae 74 (3): 997-1006.

FRIDRICH , J. 1989. Prezletice: A lower Palaeolithic site in Central Bohemia (Excavations 1969-1985). Prague: Museum Nationale Pragae.

1991. The oldest Palaeolithic stone industry from the Beroun highway complex, Antropozoikum 20:111-28.

GAGNEPAIN, J., I. HEDLEY, J.-J. BAHAIN \& J.-J. WAGNER. 1992. Etude magnétostratigraphique du site de Ca'Belvedere di Monte Poggiolo (Forli, Italie), et de son contexte stratigraphique. Premiers résultats, in Peretto (1992): 319-35.

GAMBLE, C.S. 1993. Timewalkers. The Prehistory of Global Colonization. Stroud (Gloucestershire): Alan Sutton. 1994. TIME FOR BOXGROVE MAN, NATURE 369: 275-6.

GIL, E. \& C. SESE. 1991. Middle Pleistocene small mammals from Atapuerca (Burgos, Spain), in Datations et Charactérizations des Milieux Pléistocènes. Actes du Symposium 11 et 17 de la 11ème R.S.T. Clermond Ferrand 1986. Cahiers du Quaternaire 16: 337-47.

GuTH, C. \& J. ChavaILLON. 1985. Découverte, en 1984, de nouveaux outils paléolithiques à Chilhac III, (Haute Loire), Bulletin de la Société Préhistorique Française 82: 56-64.

KASANSTEVA, N.E. 1987. Paleogeograficeskie uslovija obitanija nizneplejstocenovyx faun melkix mlekopitajuscix bassejna srednego Dona. Dissertation, University of Moscow, Moscow.

KOZLOWSKI, J.K. 1992. Les premiers habitants de l'Europe centrale et orientale, in Peretto (1992): 69-91.

KRETZOI, M. 1965. Die Nager und Lagomorphen von Voigtstedt in Thüringen und ihre chronologische Aussage, Paläontologische Abhandlungen 2(3): 587-660.

KRETZOI, M. \& M. PÉCSI. 1979. Pliocene and Pleistocene development and chronology of the Pannonian $\mathrm{Ba}-$ sin, Acta Geologica Academiae Scientiarum Hungaricae 22: 1-4, 3-33.

LISTER, A. 1992. Mammalian fossils and quaternary biostratigraphy, Quaternary Science Reviews 11 329-44.

LUMLEY, H. DE 1988. La stratigraphie du remplissage de la grotte du Vallonet, L'Anthropologie 92: 407-28.

LUMLEY, H. DE, A. FOURNIER, J. KRZEPKOWSKA \& A. ECHASSOUX. 1988. L'industrie du Pléistocène inférieur de la grotte du Vallonet, Roquebrune-Cap-Martin, Alpes-Maritimes, LAAthropologie 92: 501-614.
LUMLEY, H. DE, A. FOURNIER, Y.C. PARK, Y.YOKOYAMA \& A. DEMOUY. 1984. Stratigraphie du remplissage pléistocène moyen de la Caune de l'Arago à Tautavel Etude de huit carottages effectués de 1981 à 1983 . LAnthropologie 88: 5-18.

MALEZ, M. 1976. Excavation of the Villafranchian site Sandalja I near Pula (Yugoslavia), in: K. Valoch (ed.), Les premières industries de l'Europe. IXe Congrès UISPP, Collogue VIII: 104-23. Nice: UISPP.

MCPHERRON, A. \& V. SCHMIDT. 1983. Paleomagnetic dating at Isernia la Pineta, in C. Peretto, C. Terzani \& M. Cremaschi (ed.), Isernia la Pineta, un accampamento piu antico di 700,000 anni: 67-9. Bologna: Calderini.

MELTZER, D.J. 1993. Pleistocene peopling of the Americas, Evolutionary Anthropology 1: 157-69.

MUSIL, R. \& K. VALOCH. 1968. Stránská skála. Its meaning for Pleistocene Studies, Current Anthropology 9: 534-9.

Mussi, M. 1992. Il Paleolitico e il Mesolitico in Italia. Bologna: Stilus.

Obermaier, H. 1912. Der Mensch der Vorzeit. Berlin: Allgemeine Verlags-Gesellschaft.

PERETTO, C. (ed.). 1992. I Primi Abitanti della Valle Padana Monte Poggiolo Nel Quadro delle Conoscenze Europee. Milano: Jaca Book.

RAPOSO, L. 1985. Le Paléolithique inférieur archaïque au Portugal. Bilan des connaissances. Bulletin de la Société Préhistorique Française 82(6): 173-80.

ROBERTS, M.B. 1986. Excavation of the Lower Palaeolithic site at Amey's Eartham Pit, Boxgrove, West Sussex A preliminary report, Proceedings of the Prehistoric Society 52: 215-45.

1990. 'Amey's Eartham Pit, Boxgrove', in C. Turner (ed.). The Cromer Symposium Norwich 1990, SEQS: field excursion guide book: 62-77. Cambridge: Quaternary Research Association.

Roberts, M.B., C.B. STringer \& S.A. PARFITT, 1994. A hominid tibia from Middle Pleistocene sediments at Boxgrove, UK, Nature 369: 311-13

ROEBROEKS, W., N.J. CONARD \& T. VAN KOLFSCHOTEN. 1992 Dense forests, cold steppes and the Palaeolithic settlement of northern Europe, Current Anthropology 33: 551-86.

ROLLAND, N. 1992. The Palaeolithic colonization of Europe: an archaeological and biogeographic perspective. Trabajos de Prehistoria 49: 69-111.

SALA, B., F. MASINI, G. FicCARElli, L. ROOK \& D. TORRE. 1992. Mammal dispersal events in the Middle and Late Pleistocene of Italy and Western Europe, Courier Forschungsinstitut Senckenberg 153: 59-68.

SALA, B. \& M. ForTELIUS. 1993. The rhinoceroses of Isernia La Pineta (early Middle Pleistocene, Southern Italy), Palaeontographia Italica 80: 157-74.

SANTONJA, M. 1992. La adaptacion al medio en el Paleolitico inferior de la Peninsula ibérica. Elementos para una reflexion, in A. Moure Romanillo (ed.), Elefantes, ciervos y ovicaprinos: 37-75. Santander: Universidad de Cantabria.

Santonta, M. \& P. VILla. 1990. The Lower Palaeolithic of Spain and Portugal, Journal of World Prehistory 4: $45-94$.

SCHICK, K.D. \& D. ZHUAN. 1993. Early Paleolithic of China and Eastern Asia, Evolutionary Anthropology 2: 22-35.

SOLLAS, W.J. 1911 (1924). Ancient Hunters and their Modern Representatives. London: Macmillan. 2nd edn 1924.

SWISHER, C.C., G.H. CURTIS, T. JACOB, A.G. GETTY, A. SUPRIJO \& WIDIASMORO. 1994. Age of the earliest known hominids in Java, Indonesia, Science 263: 1118-21. 
TERZEA, E. In press. Mammalian events in the Quaternary of Romania and correlations with climatic chronology of Western Europe, Acta zoologica cracoviensia.

THIEME, H., D. MANIA, B. URBAN \& T. VAN KOlFSCHOTEN. 1993. Schöningen (Nordharzvorland). Eine altpaläolithische Fundstelle aus dem mittleren Eiszeitalter, Archäologisches Korrespondenzblatt 23: 147-63.

THOUVENY, N. \& E. BONIFAY. 1984. New chronological data on European Plio-Pleistocene faunas and hominid occupation sites, Nature 308: 355-8.

TUFFREAU, A. 1987. Le Paléolithique inférieur et moyen du Nord de la France (Nord Pas-de-Calais, Picardie) dans son cadre stratigraphique. Thèse Doctorat d'Etat Université de Lille, Lille.

TURNER, A. 1992. Large carnivores and earliest European hominids: changing determinants of resource availability during the Lower and Middle Pleistocene, Journal of Human Evolution 22: 109-26.

VALOCH, K. 1972. Gab es eine altpaläolithische Besiedlung der Stránská skála? in R. Musil (ed.), Stránská skála I 1910-1945: 199-204. Brno: Morávske Museum. Anthropos 20 (N.S. 12).

1984. Early Palaeolithic in Moravia, Czechoslovakia, Proceedings of the Prehistoric Society 50: 63-9.

1987. The Early Palaeolithic Site Stránská Skála I near Brno (Czechoslovakia), Anthropologie 25(2): 125-42. 1991. Les premiers peuplements humains en Moravie (Tchécoslovaquie), in Bonifay \& Vandermeersch (1991): 189-94.

VAN DER MEULEN, A.J. 1973. Middle Pleistocene smaller mammals from the Monte (Orvieto, Italy) with special reference to the phylogeny of Microtus (Arvicolidae, Rodentia), Quaternaria 4(17): 1-444.
VAN KOLFSCHOTEN, T. 1990. The evolution of the mammal fauna in the Netherlands and the middle Rhine Area (Western Germany) during the late Middle Pleistocene, Mededelingen Rijks Geologische Dienst 43(3): 1-69.

1993. On the origin of the Middle Pleistocene larger voles, Quaternary International 19: 47-50.

VAN KOLFSCHOTEN, T. \& E. TURNER. In press. Early Middle Pleistocene mammalian faunas from Kärlich and Miesenheim I and their biostratigraphical implications, Proceedings of the SEQS Cromer Symposium 1990.

VOLBRECHT, J. 1992. Das Altpaläolithikum aus den unteren Schichten in Kärlich. Magisterarbeit, Universität Köln, Köln.

VON KOENIGSWALD, W. \& T. VAN KOLFSCHOTEN. In press. The Mimomys-Arvicola boundary andd the enamel thickness quotient (SDQ) of Arvicola as stratigraphic markers in the Middle Pleistocene, Proceedings of the SEQS Cromer symposium 1990.

WARREN, S.H. 1920. A Natural 'Eolith' Factory beneath the Thanet Sand, Quarterly Journal of the Geological Society $76: 238-53$.

WŨ RGES, K. 1986. Artefakte aus den ältesten Quartärsedimenten (Schichten A-C) der Tongrube Kärlich, Kreis Mayen-Koblenz/Neuwieder Becken, Archäologisches Korrespondenzblatt 16: 1-6.

1991. Neue altpaläolithische Funde aus der Tongrube Kärlich, Kreis Mayen-Koblenz/Neuwieder Becken, Archäologisches Korrespondenzblatt 21: 449-55.

ZAGWIJN, W.H. 1985. An outline of the Quaternary stratigraphy of the Netherlands, Geologie en Mijnbouw 64: 17-24.

1992. The beginning of the Ice Age in Europe and its major subdivisions, Quaternary Science Reviews 11: 583-91. 